University of Nebraska - Lincoln

DigitalCommons@University of Nebraska - Lincoln

Nebraska Cooperative Fish \& Wildlife Research Nebraska Cooperative Fish \& Wildlife Research Unit -- Staff Publications

2002

\title{
Biodiversity of Fungi in Red Imported Fire Ant (Hymenoptera: Formicidae) Mounds
}

Jennifer A. Zettler

Clemson University

Thomas M. Mclnnis Jr.

Clemson University

Craig R. Allen

Clemson University, callen3@unl.edu

Timothy P. Spira

Clemson University

Follow this and additional works at: https://digitalcommons.unl.edu/ncfwrustaff

Part of the Other Environmental Sciences Commons

Zettler, Jennifer A.; McInnis, Thomas M. Jr.; Allen, Craig R.; and Spira, Timothy P., "Biodiversity of Fungi in Red Imported Fire Ant (Hymenoptera: Formicidae) Mounds" (2002). Nebraska Cooperative Fish \& Wildlife Research Unit -- Staff Publications. 49.

https://digitalcommons.unl.edu/ncfwrustaff/49

This Article is brought to you for free and open access by the Nebraska Cooperative Fish \& Wildlife Research Unit at DigitalCommons@University of Nebraska - Lincoln. It has been accepted for inclusion in Nebraska Cooperative Fish \& Wildlife Research Unit -- Staff Publications by an authorized administrator of DigitalCommons@University of Nebraska - Lincoln. 


\title{
Biodiversity of Fungi in Red Imported Fire Ant (Hymenoptera: Formicidae) Mounds
}

\author{
JENNIFER A. ZETTLER, ${ }^{1}$ THOMAS M. McINNIS, Jr., CRAIG R. ALLEN, ${ }^{2}$ and TIMOTHY P. SPIRA \\ Biological Sciences, Clemson University, Clemson, SC 29634
}

Ann. Entomol. Soc. Am. 95(4): 487-491 (2002)

\begin{abstract}
The red imported fire ant, Solenopsis invicta Buren, became established in North America more than $70 \mathrm{yr}$ ago, and it currently occupies most of the southeastern United States. Fire ants change the physical and chemical components of soil, which likely influence soil fungi in ant mounds. To determine the effects of fire ants on soil fungi, we sampled soil from fire ant mounds and the surrounding nonmound soil. In addition, we sampled soil from the nests of the native ant Aphaenogaster texana carolinensis Wheeler. We found that both fire ant mounds and native ant nests had greater fungal abundance but lower species richness and diversity than nonmound soil. Fire ant mounds contained 19 times more colony forming units ( $\mathrm{cfu}^{-1}$ ) than adjacent soil; however, nonmound soil had more than twice the number of fungal species. Two species (Papulaspora byssina Hotson and Penicillium janthinellum Biourge) made up the majority ( 54.5 and $19.2 \%$ relative colony frequencies, respectively) of fungi in fire ant mounds. These high proportions of limited numbers of fungal species in fire ant mounds indicate that only some species are tolerant to and thrive in mound conditions. Alternatively, fire ants might not selectively remove these fungi from their mounds. Given the high densities of fire ants and their frequent mound movements, changes in soil fungal communities might have lasting impacts on soil conditions. In addition, we suggest that differences between fungal communities in soil from native and non-native ant colonies might indirectly influence ant-mediated seed dispersal by affecting seedling survival.
\end{abstract}

KEY WORDS Solenopsis, Aphaenogaster, seed dispersal, fungi, Papulaspora

THE RED IMPORTED fire ant, Solenopsis invicta Buren, was established in North America in the 1930s (Lofgren 1986), and currently occupies most of the southeastern United States (Calcott and Collins 1996). Fire ants can alter ecological properties of their environments following invasion. Biotically, fire ants can negatively affect vertebrate (Allen et al. 1994), invertebrate (Porter and Savignano 1990), and yeast (Ba et al. 2000) populations. Abiotically, fire ants also may change the physical and chemical properties of soil. For example, through tunnel excavations and mound construction, subsoil is aerated as it is brought to the ground surface (Hays 1959). In addition, occupation by fire ants can change soil pH (Herzog et al. 1976, Blust et al. 1982), increase phosphorus and potassium levels (Blust et al. 1982), and reduce organic matter (Herzog et al. 1976, Blust et al. 1982). These changes in soil conditions will likely influence the microbiota found within fire ant mounds.

Ants employ several tactics as defenses against bacteria and fungi. Some ants physically remove fungi and spores from their bodies, other nestmates, and nest

\footnotetext{
${ }^{1}$ E-mail: jzettle@clemson.edu.

${ }^{2}$ U.S. Geological Survey, South Carolina Cooperative Fish and Wildlife Research Unit, Clemson University, Clemson, SC 29634
}

chambers (Hölldobler and Wilson 1990). Other ants can use chemical defense mechanisms. For example, fire ants have venom that contains alkaloids that decrease conidial germination by entomopathogenic fungi (Storey et al. 1991). Secretions from the metapleural gland of the ant Myrmecia nigriscapa Roger significantly suppress both mycelial growth (Beattie et al. 1985) and spore germination of soil fungi (Beattie et al. 1986). Leaf cutter ants that culture fungi use antibiotics from actinomycetes to suppress pathogenic fungi (Currie et al. 1999). Furthermore, secretions of alarm pheromones can inhibit fungal growth (Cole et al. 1975). These mechanical and chemical defenses conceivably influence fungal populations in ant mounds.

Given that fire ants are expanding their range, there is growing concern that their presence will have negative ecological consequences. The search for biological controls of fire ants has prompted investigations on the mycological components of fire ant colonies (Jouvenaz et al. 1977, Jouvenaz and Kimbrough 1991); however, in these studies searches were limited to endoparasites. Here we have investigated nonyeast fungi found within fire ant mounds. Our objective was to compare the fungal species richness, diversity, and composition in fire ant mounds, nonmound soil, and in 
Table 1. Fungal species richness, diversity, evenness, and number of colony forming units per gram of dry weight soil (cfu $\mathrm{g}^{-1}$ ) in five fire ant (Solenopsis invicta) mounds, five non-mound soil locations, and five Aphaenogaster texana carolinensis nests in Clemson, SC, in 2001

\begin{tabular}{lccc}
\hline \hline & Species richness & Diversity $\left(H^{\prime}\right)$ & Evenness $(E)$ \\
\hline Fire ant mounds & 14 & $1.6(0.114) \mathrm{a}$ & $0.61(0.037) \mathrm{a}$ \\
Non-mound soil & 29 & $3.1(0.141) \mathrm{b}$ & $0.92(0.061) \mathrm{b}$ \\
Aphaenogaster nests & 19 & $2.5(0.155) \mathrm{b}$ & $0.85(0.045) \mathrm{b}$ \\
\hline
\end{tabular}

Shannon-Weaver formulas were used to calculate diversity $\left(H^{\prime}\right)$ and evenness $(E)$ indexes. Numbers in parentheses are standard errors. Within-column values with the same letter are not significantly different $(P>0.05)$.

nests of the native ant Aphaenogaster texana carolinensis Wheeler (N20 of Umphrey 1996).

\section{Materials and Methods}

Soil from A. texana carolinensis nests, fire ant mounds, and nonmound areas was sampled on 30 March 2001 from two locations near Clemson, SC. Voucher specimens of A. texana carolinensis and S. invicta were deposited in the Clemson University Arthropod Collection. Soil and leaf litter from Aphaenogaster nests were collected from an eastern deciduous forest in the Clemson Experimental Forest devoid of $S$. invicta mounds. Aphaenogaster nest entrances were located by following foragers returning from tuna baits. In the second site, we sampled soil from both active fire ant mounds and nonmound areas ( $>1.0 \mathrm{~m}$ from mounds) in a dairy-cow pasture. Nonmound soil had no evidence of past occupation by fire ants. This pasture contained an average density of 37 fire ant mounds per ha. To minimize disturbance of ant colonies, we collected soil at sunrise when air temperature was $8^{\circ} \mathrm{C}$. Worker and brood were not present at the top of the mound when we collected soil samples. For each soil type (Aphaenogaster nest, fire ant mound, and nonmound), we used a soil core sampler $(5 \mathrm{~cm})$ to obtain five samples of the first $8-10 \mathrm{~cm}$ of top soil. The soil sampler was rinsed in $25 \%$ bleach $(6.0 \% \mathrm{NaOCl})$ between samples. Each sample was placed in a plastic bag, sealed, transported in an ice cooler, and returned to the laboratory. All ants and brood that remained in the samples were removed with sterile forceps, and the soil was refrigerated overnight at $4^{\circ} \mathrm{C}$.

For each sample, $10 \mathrm{~g}$ of mixed soil were added to $90 \mathrm{ml}$ of deionized water and stirred. From this mixture, 10-fold serial dilutions were prepared. Upon obtaining a final dilution of $10^{-3}$ for each sample, $1.0 \mathrm{ml}$ of the soil suspension was pipetted onto the surface of a rose bengal agar plate (100 by $15 \mathrm{~mm}$ ). Rose bengal agar media reduces bacterial growth and limits the growth of invasive fungal species (Jarvis 1973). Agar plates were incubated at room temperature $\left(\approx 25^{\circ} \mathrm{C}\right)$ for $4 \mathrm{~d}$, and an average number of colony-forming units (cfu) for all three soil types was calculated. From each plate, 20 randomly selected isolates were transferred to potato dextrose agar slants, yielding a total of 100 fungal colonies for each of the three soil types. These fungal isolates were used to calculate relative sample frequency (\% of samples with fungal species), relative colony frequency (percentage of total fungal colonies present), Shannon-Weaver diversity $\left(H^{\prime}\right)$ and evenness $(E)$ indexes (Shannon and Weaver 1949), and coefficients of similarity in each soil type. Isolates that failed to grow or were identified as actinomycetes or yeasts were not included in the analyses. We obtained wet and dry (oven dried at $105^{\circ} \mathrm{C}$ for $72 \mathrm{~h}$ ) (Winegardner 1996) weights of $\approx 5 \mathrm{~g}$ soil from each of the remaining soil samples to quantify the number of colony-forming units $\left(\mathrm{cfu} \mathrm{g}^{-1}\right)$. Average number of cfu g ${ }^{-1}$ and Shannon-Weaver indexes were analyzed by a one-way analysis of variance (ANOVA) followed by a Tukey's multiple comparison test where warranted (SAS Institute 1999).

One fungus, Papulaspora byssina Hotson (=anamorph of Myriococcum praecox Fr.) growing on agar slants, was presented to five fire ant colonies. Each colony was presented one agar slant. After $1 \mathrm{~h}$, the numbers of fire ants foraging on each slant were recorded. In addition, we simultaneously presented uninoculated agar slants to five additional fire ant colonies to determine if fire ants preferentially forage on $P$. byssina. Total numbers of ants foraging were compared with a one-way ANOVA (SAS Institute 1999).

\section{Results}

We found that the mean cfu varied for the three soil types. Fire ant mounds had a significantly $\left(F_{2,27}=6.69\right.$, df $=2, P=0.004)$ higher number $($ mean $=415, \mathrm{SE}=$ 128) of cfu than adjacent nonmound soil ( mean $=22$, $\mathrm{SE}=3.78$ ), but no significant difference existed between cfu in fire ant mounds and Aphaenogaster nests $($ mean $=169, \mathrm{SE}=30.3)$. Based on calculated $\mathrm{cfu}^{-1}$, fire ant mounds had more than twice the number of fungi as Aphaenogaster nests $(227,052)$, but these differences were not significant $(P>0.05)$ (Table 1$)$. Fire ant mounds had $>19$ times the number of $\mathrm{cfu} \mathrm{g}^{-1}$ $(503,390)$ than did nonmound soil $(25,995)$ (Table 1$)$. However, most of the fungi in fire ant mounds consisted of only two species, Papulaspora byssina Hotson (55\%) and Penicillium janthinellum Biourge (19\%) (Table 2). We found that fire ants might not be harvesting $P$. byssina for consumption because there were significantly $\left(F_{1,8}=8.27, \mathrm{df}=1, P=0.020\right)$ more ants foraging on uninoculated agar than agar with $P$. byssina. Papulaspora byssina was found in low numbers (2.4\%) in Aphaenogaster nests; however nonmound soil lacked this fungus (Table 2). Penicillium janthinellum was found in the nonmound soil, but its relative colony frequency was only $2.6 \%$ (Table 2 ). 
Table 2. Relative sample frequency (\% of samples with fungal species) and relative colony frequency (\% of total fungal colonies present) of fungal species found in soil collected in Clemson, $\mathbf{S C}$, in March 2001 from five red imported fire ant (Solenopsis invicta) mounds, five non-mound soil locations, and five Aphaenogaster texana carolinensis nests

\begin{tabular}{|c|c|c|c|c|c|c|}
\hline \multirow[b]{2}{*}{ Fungal species } & \multicolumn{2}{|c|}{ S. invicta } & \multicolumn{2}{|c|}{ Non-mound soil } & \multicolumn{2}{|c|}{ A. texana carolinensis } \\
\hline & $\begin{array}{c}\text { Sample } \\
\text { frequency }\end{array}$ & $\begin{array}{c}\text { Colony } \\
\text { frequency }\end{array}$ & $\begin{array}{c}\text { Sample } \\
\text { frequency }\end{array}$ & $\begin{array}{c}\text { Colony } \\
\text { frequency }\end{array}$ & $\begin{array}{c}\text { Sample } \\
\text { frequency }\end{array}$ & $\begin{array}{c}\text { Colony } \\
\text { frequency }\end{array}$ \\
\hline Absidia cylindrospora Hagem. & - & - & - & - & 20 & 1.2 \\
\hline Absidia spinosa Lendn & - & - & 40 & 2.6 & 40 & 2.4 \\
\hline Aspergillus flavipes (Bainier and Sartory) Thom and Church & - & - & 20 & 1.3 & - & - \\
\hline Cladosporium cladosporioides (Fresen.) deVries & - & - & 40 & 3.8 & - & - \\
\hline Fusarium sp. 1 Link & - & - & 80 & 9.0 & - & - \\
\hline Fusarium sp. 2 & 40 & 2.0 & - & - & - & - \\
\hline Fusarium sp. 3 & 40 & 3.0 & 40 & 5.1 & - & - \\
\hline Fusarium sp. 4 & - & - & - & - & 60 & 3.6 \\
\hline Fusarium sp. 5 & - & - & 40 & 2.6 & - & - \\
\hline Fusarium sp. 6 & - & - & 20 & 1.3 & - & - \\
\hline Fusarium sp. 7 & - & - & 20 & 1.3 & - & - \\
\hline Fusarium culmorum (W. G. Smi.) Sacc. & - & - & 40 & 2.6 & - & - \\
\hline Fusarium dimerum Penz & - & - & 20 & 2.6 & - & - \\
\hline Fusarium merismoides Corda & 40 & 2.0 & - & - & - & - \\
\hline Fusarium oxysporum Fr. & - & - & 60 & 15.4 & - & - \\
\hline Gliocladium sp. 1 Corda & - & - & 20 & 1.3 & - & - \\
\hline Gliocladium sp. 2 & - & - & 40 & 2.6 & - & - \\
\hline Gongronella butleri (Lendn.) Peyronel and Dal Vesco & - & - & 20 & 3.8 & 40 & 2.4 \\
\hline Mortierella sp. 1 Coem & - & - & - & - & 60 & 8.3 \\
\hline Mortierella sp. 2 & - & - & 20 & 1.3 & 100 & 10.7 \\
\hline Mortierella sp. 3 & - & - & - & - & 40 & 3.6 \\
\hline Mucor hiemalis Wehmer & 20 & 4.0 & - & - & - & - \\
\hline Mycelia sterile sp. 1 & 20 & 1.0 & - & - & 60 & 4.8 \\
\hline Mycelia sterile sp. 2 & - & - & 40 & 3.8 & - & - \\
\hline Papulaspora byssina Hotson & 100 & 54.5 & - & - & 40 & 2.4 \\
\hline Penicillium sp. 1 Link & 20 & 1.0 & 20 & 2.6 & - & - \\
\hline Penicillium sp. 2 & 20 & 1.0 & - & - & 100 & 25.0 \\
\hline Penicillium sp. 3 & 20 & 1.0 & - & - & 80 & 13.1 \\
\hline Penicillium sp. 4 & 20 & 1.0 & 40 & 2.6 & - & - \\
\hline Penicillium sp. 5 & - & - & 20 & 5.1 & - & - \\
\hline Penicillium sp. 6 & - & - & 40 & 2.6 & - & - \\
\hline Penicillium sp. 7 & - & - & - & - & 20 & 1.2 \\
\hline Penicillium corylophilum Dierckx & - & - & - & - & 40 & 2.4 \\
\hline Penicillium herquei Bainier and Sartory & - & - & 20 & 1.3 & 60 & 7.1 \\
\hline Penicillium janthinellum Biourge & 100 & 19.2 & 20 & 2.6 & - & - \\
\hline Penicillium rubrum Sopp & - & - & 20 & 1.3 & - & - \\
\hline Ramichloridium sp. Stahel ex de Hoog & 20 & 2.0 & - & - & - & - \\
\hline Rhizopus sp. Link & - & - & 40 & 6.4 & - & - \\
\hline Rhizopus stolonifer (Ehrenb.) Vuill. & - & - & 20 & 1.3 & - & - \\
\hline Trichoderma sp. 1 Pers. & - & - & 20 & 2.6 & - & - \\
\hline Trichoderma sp. 2 & - & - & 20 & 2.6 & 20 & 1.2 \\
\hline Trichoderma sp. 3 & - & - & - & - & 40 & 2.4 \\
\hline Trichoderma polysporum (Link) Rifai & 20 & 6.1 & - & - & 20 & 1.2 \\
\hline Trichoderma pseudokoningii Rifai & - & - & - & - & 60 & 6.0 \\
\hline Verticillium lecanii (Zimm.) Viégas & - & - & 20 & 1.3 & - & - \\
\hline Zygorhynchus moelleri Vuill. & 20 & 2.0 & 20 & 7.7 & 20 & 1.2 \\
\hline
\end{tabular}

Of the 100 fungal isolates from each location (fire ant mounds, nonmound soil, and Aphaenogaster nests), 1, 22, and $16 \%$ of the samples, respectively, could not be included in the analyses as a result of bacterial, yeast, or actinomycete growth. Fungal diversity was significantly $\left(F_{2,12}=18.81\right.$, df $=2, P=$ $0.000)$ lower in fire ant mounds, than in both Aphaenogaster nests and nonmound soil (Table 1). Species evenness was also significantly lower $\left(F_{212}=23.81\right.$, $\mathrm{df}=2, P=0.000)$ in fire ant mounds than in both Aphaenogaster nests and nonmound soil (Table 1). The number of fungal species in nonmound soil was higher than that found in fire ant mounds and Aphaenogaster nests (Table 1). Based on coefficients of similarity, there was little overlap in fungal species between sites. Fire ant mounds shared only $23.3 \%$ of fungi with adjacent, nonmound soil and $36.4 \%$ of fungi from Aphaenogaster nests. Nonmound soil and Aphaenogaster nests had the lowest coefficient of similarity (20.8). Out of 46 total fungi identified, only one, $\mathrm{Zy}$ gorhynchus moelleri Vuill., was found in all three sites (fire ant mounds, nonmound soil, and Aphaenogaster nests); however, its relative colony frequencies were low $(2.0,1.2$, and 7.7 , respectively).

\section{Discussion}

Fire ant mounds contained 19 times more fungal colonies $\left(\mathrm{cfu} \mathrm{g}^{-1}\right)$ than adjacent soil. Our results are consistent with those of Czerwiñski et al. (1971) who found a 10-fold increase in the number of cfu in Lasius niger L. mounds and a three-fold increase in Myrmica 
sp. Latreille mounds in comparison with uninhabited soil. Czerwiñski et al. (1971) did not identify fungal species, but we found that one species, P. byssina, dominated fire ant mounds. This fungus also was found in Aphaenogaster nest samples but in low relative numbers. Based on collection information, Hotson (1917) suggests that $P$. byssina is limited to horse dung; however, little is known about this fungus. Because Aphaenogaster spp. consume Agaricales mushrooms (Carroll et al. 1981), it is possible S. invicta and A. texana carolinensis are gathering P. byssina for food. However, we found that fewer fire ants foraged on cultures of $P$. byssina than on uninoculated agar. Our study was limited to one site, and more research is needed to determine if the ant-fungal associations we identified are widespread.

Fire ant mounds had lower fungal species richness, diversity, and evenness than Aphaenogaster nests (Table 1). Because Aphaenogaster nests average $12 \mathrm{~cm}$ deep, and upper nest chambers consist of leaf litter (Talbot 1951), these ants do not make discernable mounds. Due to the shallow construction of Aphaenogaster nests, less soil and more leaf litter was obtained from Aphaenogaster nest chambers than in S. invicta mounds. Therefore, lack of similarities between fungal species in fire ant mounds and Aphaenogaster nests might be explained by differences in nest construction.

We found that both fire ant mounds and native ant nests had lower fungal species richness and diversity than nonmound soil (Table 1). Differences among fungal diversity in Aphaenogaster nests, fire ant mounds, and the nonmound soil might also be a result of variations in environmental conditions such as temperature, moisture, nutrients, $\mathrm{pH}$, and aeration in these microhabitats. Alternatively, these fungal differences might be due to the presence of antimicrobial defenses in ants and degrees of fungal resistance to these defenses. For example, secretions from metapleural glands can significantly reduce hyphal growth in Aspergillus niger Tiegh, Cladosporium resinae (Lindau) DeVries, Gliocladium roseum Bain, Penicillium aurantiogriseum Dierckx, Trichoderma viride Pers., Beauveria bassiana Bals. Vuill., and Paecilomyces lilacinus (Thom.) Samson (Beattie et al. 1985). Although metapleural secretions are nonspecific antimicrobials on gram-positive and gram-negative bacteria and yeasts (Veal et al. 1992), Beattie et al. (1985) found that one fungal species, Metarhizium brunneum Petch, showed resistance to metapleural secretions. Alkaloids from venom glands of S. invicta inhibit conidial germination, but they have little effect on hyphae (Storey et al. 1991). Therefore, it is possible that vegetative bulbils of $P$. byssina are resistant to fire ant defenses. In addition, fungi themselves can produce antibiotics and antifungal agents, which can inhibit growth of other fungal species. For example, $P$. janthinellum is known to produce agents that can limit the growth of other fungal species (Domsch et al. 1980). This may, in part, explain why nonmound soil contained higher fungal diversity than ant-occupied soils (Table 1). In addition, we found the highest proportion of bacteria, yeasts, and actinomycetes in our isolates from nonmound soil ( $22 \%$ contaminated), whereas fire ant mounds had the lowest percent (1\% contaminated). We found that fire ant mounds had the highest cfu $\mathrm{g}^{-1}$; however, species richness in fire ant mounds was reduced by over $50 \%$ compared with the surrounding soil. These high densities of limited numbers of fungal species in fire ant mounds possibly indicate that only some species (such as P. byssina and $P$. janthinellum) are tolerant to and thrive in mound conditions. Additional studies are needed to determine specific factors that limit fungal diversity in antoccupied soils.

Native ants in the genus Aphaenogaster are involved in an apparent ant-seed mutualism whereby plants (myrmecochores) recruit ants to disperse seeds to their nests, which are favorable sites for seedling establishment (Handel 1978). Once ants discard the seed, both pathogenic and nonpathogenic fungi in the soil can hinder seedling recruitment by lowering seed viability (Baskin and Baskin 1998). It is unknown how differences in fungal populations in ant-occupied soil can affect the apparent mutualism between native, seed-dispersing ants and myrmecochorous plants. We found a reduction in fungal species in ant-occupied soils. Plants grown in ant nests might be more successful than those plants in surrounding soils (Culver and Beattie 1980) because seeds taken to ant nests might benefit by a reduction in plant pathogens. Ant nests might even provide ideal growing conditions for slowly developed mycorrhizae associated with myrmecochores (Brundrett and Kendrick 1990). Further studies are needed to investigate the fungi found in ant-occupied soil to explain any possible advantage of having directed seed dispersal.

The introduction of non-native ants into fynbos habitats in South Africa has negatively affected myrmecochores by reducing seedling emergence, and Bond and Slingsby (1984) suggested that this introduction can impact plant community composition by reducing seedling recruitment. In the southeastern United States, fire ants are attracted to and destroy the seeds of myrmecochores, and seeds that escape consumption have their seed coat removed (scarified) (Zettler et al. 2001). Scarification of seeds can allow fungi to invade and cause seed mortality (Kremer and Spencer 1989). Through the production of enzymes and toxins, fungi can cause seed mortality (Baskin and Baskin 1998). Once fire ants abandon a mound, it is unknown how long fungal differences between the nonmound and mound soil will remain. Through frequent colony movement, fire ants might have longterm effects on soil fungi. Thus, differences in fungi found in fire ant mounds and native ant nests may further disrupt the mutualistic relationship between native ants and myrmecochores.

\section{Acknowledgments}

We thank S. T. Brock, T. L. Harris, V. M. Howell, and B. W. Robertson for technical support, P. H. Adler, D. W. Tonkyn, F. W. Zettler, and L. W. Zettler for providing helpful com- 
ments on the manuscript, and G. J. Umphrey for Aphaenogaster identification. The South Carolina Cooperative Fish and Wildlife Research Unit is jointly supported by a cooperative agreement among the USGS/BRD, the South Carolina Department of Natural Resources, Clemson University, and the Wildlife Management Institute. This research was partially supported by a grant from the Clemson University Enhancement of Research and Extension Programs in Imported Fire Ant Biology.

\section{References Cited}

Allen, C. R., S. Demarais, and R. S. Lutz. 1994. Red imported fire ant impact on wildlife: an overview. Tex. J. Sci. 46: 51-59.

Ba, S. A., S. A. Phillips, Jr., and J. T. Anderson. 2000. Yeasts in mound soil of the red imported fire ant. Mycol. Res. 104: 969-973.

Baskin, C. C., and J. M. Baskin. 1998. Seeds: ecology, biogeography, and evolution of dormancy and germination. Academic, San Diego, CA.

Beattie, A. J., C. L. Turnbull, T. Hough, S. Jobson, and R. Bruce Knox. 1985. The vulnerability of pollen and fungal spores to ant secretions: evidence and some evolutionary implications. Am. J. Bot. 72: 606-614.

Beattie, A. J., C. L. Turnbull, T. Hough, and R. Bruce Knox. 1986. Antibiotic production: A possible function for the metapleural glands of ants (Hymenoptera: Formicidae). Ann. Entomol. Soc. Am. 77: 448-450.

Blust, W. E., B. H. Wilson, K. L. Koonce, B. D. Nelson, and J. E. Sedberry. 1982. The red imported fire ant, Solenopsis invicta Buren: cultural control and effect on hay meadows. Bull. La. Agric. Exp. Stn. 738.

Bond, W., and P. Slingsby. 1984. Collapse of an ant-plant mutualism: the Argentine ant (Iridiomyrmex humilis) and myrmecochorous Proteaceae. Ecology 65: 1031-1037.

Brundrett, M., and B. Kendrick. 1990. The roots and mycorrhizas of herbaceous woodland plants. New Phytol. 114: 457-468.

Calcott, A. A., and H. L. Collins. 1996. Invasion and range expansion of imported fire ants (Hymenoptera: Formicidae) in North America from 1918-1995. Fla. Entomol. 79: 240-251.

Carroll, J. F., J. W. Kimbrough, and W. H. Whitcomb. 1981. Mycophagy by Aphaenogaster spp. (Hymenoptera: Formicidae). Proc. Entomol. Soc. Wash. 83: 326-331.

Cole, L. K., M. S. Blum, and R. W. Roncadori. 1975. Antifungal properties of the insect alarm pheromones, citral, 2-heptanone, and 4-methyl-3-heptanone. Mycologia 67: 701-708.

Culver, D. C., and A. J. Beattie. 1980. The fate of Viola seeds dispersed by ants. Am. J. Bot. 67: 710-714.

Currie, C. R., J. A. Scott, R. C. Summerbell, and D. Malloch. 1999. Fungus-growing ants use antibiotic-producing bacteria to control garden parasites. Nature (Lond.) 398: 701-704.

Czerwiñski, Z., H. Jakubczyk, and J. Petal. 1971. Influence of ant hills on meadow soils. Pedobiologia 11: 277-285.

Domsch, K. H., W. Gams, and Traute-Heidi Anderson. 1980. Compendium of soil fungi. Academic, London.

Handel, S. N. 1978. The competitive relationship of three woodland sedges, and its bearing on the evolution of ant dispersal of Carex pedunculata. Evolution 32: 151-163.
Hays, K. L. 1959. Ecological observations on the imported fire ant, Solenopsis saevissima richteri Forel, in Alabama. J. Ala. Acad. Sci. 30: 14-18.

Herzog, D. C., T. E. Reagan, D. C. Sheppard, K. M. Hyde, S. S. Nilakhe, M.Y.B. Hussein, M. L. McMahon, R. C. Thomas, and L. D. Newsom. 1976. Solenopsis invicta Buren: Influence on Louisiana pasture soil chemistry. Environ. Entomol. 5: 160-162.

Hölldobler, B., and E. O. Wilson. 1990. The ants. The Belknap Press of Harvard University Press, Cambridge, MA.

Hotson, J. W. 1917. Notes on bulbiferous fungi with a key to described species. Bot. Gaz. 64: 265-284.

Jarvis, B. 1973. Comparison of an improved rose bengalchlortetracycline agar with other media for the selective isolation and enumeration of moulds and yeasts in foods. J. Appl. Bact. 36: 723-727.

Jouvenaz, D. P., G. E. Allen, W. A. Banks, and D. P. Wojcik. 1977. A survey for pathogens of fire ants, Solenopsis spp., in the southeastern United States. Fla. Entomol. 60: 275279 .

Jouvenaz, D. P., and J. W. Kimbrough. 1991. Myrmecomyces annellisae gen. nov. (Deuteromycotina: Hyphomycetes), an endoparasitic fungus of fire ants, Solenopsis spp. (Hymenoptera: Formicidae). Mycol. Res. 95: 1395-1401.

Kremer, R. J., and N. R. Spencer. 1989. Impact of a seedfeeding insect and microorganisms on velvetleaf (Abutilon theophrasti) seed viability. Weed Sci. 37: 211216.

Lofgren, C. S. 1986. The economic importance and control of imported fire ants in the United States, pp. 222-251. In S. B. Vinson (ed.), Economic impact and control of social insects. Praeger, New York.

Porter, S. D., and D. A. Savignano. 1990. Invasion of polygyne fire ants decimates native ants and disrupts arthropod community. Ecology 71: 2095-2106.

SAS Institute. 1999. User's manual, version 8. SAS Institute, Cary, NC.

Shannon, C. E., and W. Weaver. 1949. The mathematical theory of communication. Universtiy of Illinois Press, Urbana.

Storey, G. K., R. K. Vander Meer, D. G. Boucias, and C. W. McCoy. 1991. Effects of fire ant (Solenopsis invicta) venom alkaloids on the in vitro germination and development of selected entomogenous fungi. J. Invertebr. Pathol. 58: 88-95.

Talbot, M. 1951. Populations and hibernating conditions of the ant Aphaenogaster (Attomyrma) rudis Emery. Ann. Entomol. Soc. Am. 44: 302-307.

Umphrey, G. J. 1996. Morphometric discrimination among sibling species in the fulva-rudis-texana complex of the ant genus Aphaenogaster (Hymenoptera: Formicidae). Can. J. Zool. 74: 528-559.

Veal, D. A., J. E. Trimble, and A. J. Beattie. 1992. Antimicrobial properties of secretions from the metapleural glands of Myrmecia gulosa (the Australian bull ant). J. Appl. Bacteriol. 72: 188-194.

Winegardner, D. L. 1996. An introduction to soils for environmental professionals. Lewis, Boca Raton, FL.

Zettler, J. A., T. P. Spira, and C. R. Allen. 2001. Ant-seed mutualisms: Can red imported fire ants sour the relationship? Biol. Conserv. 101: 249-253.

Received for publication 14 December 2001; accepted 29 March 2002 